
K
$\begin{array}{llllllllllllllll} & \mathbf{M} & \mathbf{U} & \mathrm{N} & \mathrm{I} & \mathrm{K} & \mathrm{A} & \mathbf{T} & \mathbf{Y}\end{array}$
M A T
$\begin{array}{lllllll} & \text { E } & \mathbf{R} & \text { I } & \text { A } & \mathbf{L} & \mathbf{Y}\end{array}$

Piotr Daszkiewicz

Instytut Historii Nauki im. L. i A. Birkenmajerów PAN

\title{
DZIEWIĘTNASTOWIECZNA FRANCUSKA PRÓBA ZAKUPU GDAŃSKIEJ KOLEKCJI BURSZTYNÓW GEORGA CARLA BERENDTA (1790-1850)
}

W zbiorach Instytutu Francuskiego (Institut de France) i Narodowego Muzeum Historii Naturalnej (MNHN) w Paryżu przechowywane są archiwalia, w tym licząca setki dokumentów korespondencja, związane z Pierre-Louis-Antoinem Cordierem (1777-1861), jednym z najwybitniejszych mineralogów i geologów dziewiętnastego wieku. Ze względu na swój dorobek naukowy m.in w dziedzinie wulkanologii, petrologii, zastosowania mikroskopii do badań geologicznych i geofizycznych oraz z powodu pełnienia stanowisk m.in. profesora i dyrektora Narodowego Muzeum Historii Naturalnej czy naczelnego inżyniera górnictwa Francji, członka wielu ministerialnych komisji oraz założyciela i przewodniczącego Francuskiego Towarzystwa Geologicznego, uczony ten korespondował z nieomal wszystkimi geologami w Europie i Ameryce.

W Instytucie Francuskim w zbiorze listów P-.A.-L. Cordiera znajduje się pięć li-

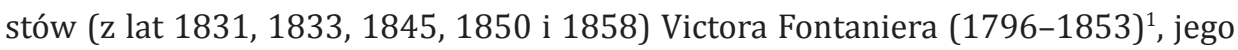
ucznia, przyrodnika, farmaceuty i dyplomaty. Odznaczył się on w służbie dyplomatycznej w krajach uznawanych wówczas za bardzo trudne dla podobnej pracy m.in. Turcji i okupowanej jeszcze Grecji, Egipcie, krajach Zatoki Perskiej, Chinach, Indiach i Indonezji. Był bardzo cenionym w tamtych czasach specjalistą od Bliskiego i Dalekiego Wschodu, autorem kilku prac opisujących podróże i zwiedzane kraje ${ }^{2}$. W trakcie każdej dyplomatycznej podróży V. Fontanier zbierał okazy geologiczne i przesyłał je do MNHN. Paryskie muzeum zawdzięcza mu m.in. znaczący zbiór minerałów

\footnotetext{
${ }^{1}$ Ms 2723 / 224-228.

${ }^{2}$ M.in. trzytomowych Voyage en Orient entrepris par ordre du gouvernement français de l'année 1821 à l'année 1829 et de 1830 à 1833 (1829-1834) i Voyage dans l'Inde et dans le Golfe Persique par l'Égypte et la Mer Rouge (1844-1846) oraz Voyage dans l'archipel indien (1852).
} 
z Indii. Jeden z listów został wysłany z Gdańska i stanowi interesujący przyczynek dla historii kolekcji przyrodniczych w naszej części Europy.

V. Fontanier informuje w liście o śmierci G.C. Berendta ${ }^{3}$, który „poświęcił wiele czasu i pieniędzy na zgromadzenie kolekcji bursztynów” i pyta, czy Narodowe Muzeum Historii Naturalnej w Paryżu byłoby zainteresowane zakupem i czy dysponuje odpowiednimi środkami. Kolekcja G.C. Berendta cieszyła się w Europie niemałą renomą. Część jej entomologicznych inkluzji opisał sam właściciel. Gdański uczony, wybitny okulista, członek, a w latach 1837-1845 przewodniczący, gdańskiego Naturforschende Gesellschaft, był znanym w dziewiętnastym wieku specjalistą bursztynowych inkluzji, autorem wydanej w Berlinie dwutomowej pracy o śladach życia dawnego świata w bursztynie Die im Bernstein befindlichen organischen Reste der Vorwelt (1845-1856) i przygotowanej wspólnie z Heinrichem Göppertem (18001884) książki o inkluzjach roślinnych Der Bernstein und die in ihm befindlichen Pflanzenreste der Vorwelt (1845), a także ogłoszonej we Francji w „Annales de la Société Entomologique de France” rozprawy o karaczanowatych w bursztynie Mémoire pour servir à l'histoire des blattes antédiluviennes (rozprawa przedstawiona na posiedzeniu Francuskiego Towarzystwa Entomologicznego 16 marca 1836 r.).

W wydanej w 1830 r. w Gdańsku pracy Die Insecten im Bernstein opisanych jest szereg gatunków z różnych rzędów i mowa o kolekcji liczącej 1200 okazów, w tym 700 zawierających inkluzje z owadami. W chwili śmierci G.C. Berendta jego kolekcja liczyła ponad 4000 okazów, w tym około 3200 z inkluzjami zwierzęcymi i 350 roślinnymi. Uznawana była za jeden z najważniejszych, o ile nie najważniejszy, tego rodzaju zbiór na świecie. Oglądali ją m.in. Aleksander Humboldt i król pruski Fryderyk Wilhelm IV. W 1847 r. około 200 okazów zostało zakupionych przez British Museum ${ }^{4}$. Nic dziwnego, że V. Fontanier informował P.-A.-L. Cordiera o możliwości jej zakupu, w dodatku na bardzo korzystnych warunkach, dla paryskiego muzeum. Do zakupu jednak nie doszło, a w zbiorach Instytutu Francuskiego ani Narodowego Muzeum Historii Naturalnej nie zachowała się ewentualna odpowiedź P-.A.-L. Cordiera na list z propozycją zakupu kolekcji. Zbiór nabył król pruski dla Uniwersytetu w Berlinie i obecnie stanowi on część zbiorów muzeum przyrodniczego Uniwersytetu Humboldta. W 1854 r. wybitny arachnolog Carl Ludwig Koch (1778-1857) opublikował befindlichen Myriapoden, Arachniden und Apteren der Vorwelt. Praca ta oparta jest na analizie okazów kolekcji G.C. Berendta. Po dzień dzisiejszy stanowi ona cenny materiał dla badań naukowych, zwłaszcza paleoentomoloicznych ${ }^{5}$.

\footnotetext{
${ }^{3}$ Na temat życia i pracy naukowej tego uczonego patrz: H.J. Kä mp fert: Georg Carl Berendt in der Naturforschenden Gesellschaft zu Danzig, als Mediziner und Erforscher der Einschlüsse im Bernstein, [w:] G. G o r n i g (red.), „Deutsch-polnische Begegnung zu Wissenschaft und Kultur, Schriftenreihe der Danziger Naturforschenden Gesellschaft" 2004 (6) s. 21-31.

${ }^{4}$ A.J. Ross: The history of the amber collection at the Natural History Museum, London, "Quekett Journal of Microscopy" 2004 (39), s. 723-728.

${ }^{5}$ Patrznp.:K.M a j e r:Rhadalinaefrom the BalticAmber(Coleoptera,Dasytidae),,DeutscheEntomologische Zeitschrift" 1998 (45/2) s. 255-264; M.S. E n g e l, D.A. G r i m a l d i, K. Kr i s h n a :
} 
Polskie tłumaczenie listu:

\section{Panie i drogi Profesorze,}

Gdańsk, 23 lutego 1850

w ubiegłym miesiącu zostałem wysłany do Gdańska, ale ponieważ nakazano mi natychmiastowy wyjazd, nie mogłem, jak to mam w zwyczaju, pożegnać się z Panem przed wyjazdem i odebrać Pańskich instrukcji. Mimo to gdy nadarzy się okazja, chciałbym być użyteczny dla Pana i być może nadarza się ona dzisiaj. Właśnie zmarł w tym mieście Doktor Berend[t], który poświęcił wiele czasu i pieniędzy na zgromadzenie kolekcji bursztynów. Rozpoczął opisywanie w nich kopalnych owadów. Kolekcja zostanie wystawiona na sprzedaż i rodzina ma jedynie niewielką nadzieję, że zakupi ją rząd, co uczyniłby normalnie w przeszłości. Ma on poważniejsze i naglejsze zmartwienia niż badanie owadów i obawiam się, że podobnie sytuacja ma się także gdzie indziej, choćby u nas. Jednakże zważywszy na okoliczności, trzeba będzie sprzedać ją tanio i być może Muzeum miałoby środki na korzystny zakup, jeśli podobna kolekcja jest wystarczająco interesująca i jeśli przyznane na powiększanie zbiorów środki pozwalają na jej zakup. Ponieważ ten ostatni warunek wydaje mi się bardzo problematyczny, nie chciałem podjąć żadnych kroków wskazujących zainteresowanie francuskiego rządu jej zakupem. Nie poprosiłem nawet o jej pokazanie, ponieważ sprzedaż nie jest jeszcze ogłoszona i w rezultacie publiczność nie została zaproszona do oglądania jej. Podjęcie jakichkolwiek zabiegów bez pewności, czy będzie możliwość dokonania zakupu, mogłoby dać rodzinie złudzenia i przeszkodzić innym transakcjom. Ograniczam się więc jedynie do uprzedzenia Pana. Jeśli odpowie mi Pan, że jest to sprawa do rozważenia i że Muzeum może interweniować w pewnych granicach, to poproszę w odpowiednim czasie o szczegóły i je Panu przekażę, w przeciwnym razie lepiej powstrzymać się do jakichkolwiek działań. Pod względem geologicznym kolekcja ta ma, jak się wydaje, mieć zasługę pokazania bursztynu $\mathrm{w}$ warstwach bituminu. Złoże to nie jest tym, które przypisuje mu się w Gdańsku. W okolicach miasta znajduje się go zmieszanego z rzecznym piaskiem, nad brzegiem morza i kopiąc w terenach napływowych, tworzących glebę. Proszę zauważyć, że ten teren napływowy wypełniony jest okruchami pochodzącymi z pierwotnych skał. Mieszkańcy mówią, że skały te są dokładnie takie same jak w Szwecji.

Czy bursztyn występuje warstwami lub w formie żył?

Widziałem w Berlinie Pana Humboldta, który kontynuuje w bardzo dobrym zdrowiu swoje życie polityczno-naukowe. Dał mi drugi tom Cosmosu, który wydał mi się mniej zagmatwany w oryginale „brouillé»], ale i mniej znaczący [w oryginale „substantiel”] niż pierwszy. Pytał mnie o Pańskie nowiny, podobnie jak i o licznych

A synopsis of Baltic amber termites (Isoptera), „Stuttgarter Beiträge zur Naturkunde Serie B (Geologie und Paläontologie)” 2007 (372) s. 1-20. 
Pańskich kolegów. Był tak pełen admiracji wobec Pana Valenciennes ${ }^{6}$, że wydało mi się to przesadzone. Starałem się jak najlepiej uspokoić go mówiąc, że nadal jest bardzo tłusty.

Z wyrazami szacunku dla Pana Drogiego profesora

Pana skromny i usłużny

V. Fontanier

6 Achille Valenciennes (1794-1865), ichtiolog i parazytolog, współpracownik Georgesa Cuviera. 